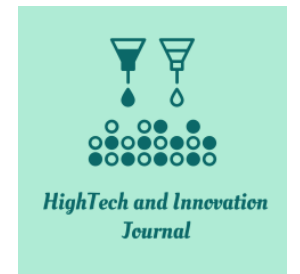

ISSN: 2723-9535

\title{
3D Numerical Modeling to Evaluate the Thermal Performance of Single and Double U-tube Ground-coupled Heat Pump
}

\author{
Ali H. Tarrad ${ }^{1 *} \mathbb{C}$ \\ ${ }^{I}$ Professor, Ph.D. Mechanical Engineering, Université de Lorraine, CNRS, LEMTA, F-54000 Nancy, France.
}

Received 26 December 2021; Revised 08 February 2022; Accepted 18 February 2022; Available online 19 February 2022

\begin{abstract}
The heat transfer rate and borehole design represent great challenges to the thermal equipment designer of the groundcoupled heat pump. The present model represents a mathematical and numerical technique implemented to tackle such a problem. A thermal assessment was established to estimate the total energy dissipated to the ground zone for a heat pump utilized for cooling purposes in the summer season. Comsol Multiphysics 5.4 software was used to build a 3-dimensional model to assess the thermal performance of single and double U-tube boreholes that circulate water as a thermal transfer medium. The (Heat Transfer) module has been implemented for this investigation under the (Stationary) study option. The model couples both heat conduction in solids, including tube metal, grout, and soil regions, and thermal medium fluid flow inside the U-tubes. The numerical solutions were compared for both heat exchangers at fixed borehole geometry, diameter, and depth and constant operating conditions in a steady-state mode. The double U-tube heat exchanger was tested in the parallel circuiting orientation of the U-tubes. The total mean resistance of the single U-tube borehole was higher than the half-loading double U-tube heat exchangers by $14.6 \%$. The results also revealed that the heat transfer rate enhancement for the double U-tube was in the range of $10-14 \%$ when operating at the same fluid mass flow rate and inlet temperature for a given borehole design.
\end{abstract}

Keywords: Borehole Design; Ground-Coupled Heat Pump; Numerical Modeling; Thermal Performance.

\section{Introduction}

The ground is considered one of the most important, clean, cheap, and sustainable natural energy sources on earth. Since the forties of the last century, the ground has been utilized as an energy source, energy sink, or energy storage. Hence, the ground has received significant attention from scientists to develop a proper technology to be coupled with the earth and take advantage of its privilege as a natural energy source. The ground heat exchanger plays a vital role in the energy transmission philosophy to or from heat storage. Therefore, qualitative and quantitative efforts were focused on the thermal design of the ground vertical and horizontal heat exchanger orientations. The enhancement of the thermal performance of ground-coupled heat pumps has led to tremendous research to optimize the borehole design and grouting methods.

The borehole depth is much larger than its diameter; hence, the heat transfer mechanism in the borehole and heat exchanger is usually formulated by a 1-dimensional line source, Ingersoll et al. [1]; Muttil and Chau [2]. It was also analyzed as the cylindrical-source theory by Ingersoll et al. [3], Carslaw et al. [4], and Kavanaugh [5]. Zeng and Fang [6] and Zeng et al. [7] presented a 2-dimensional finite line-source model to consider axial heat flow in the ground for

\footnotetext{
* Corresponding author: ali.tarrad@univ-lorraine.fr

dol) http://dx.doi.org/10.28991/HIJ-2022-03-02-01
}

$>$ This is an open access article under the CC-BY license (https://creativecommons.org/licenses/by/4.0/).

(C) Authors retain all copyrights. 
longer durations. The temperature variation inside the borehole is usually slow and minor. As a result, except for analyses dealing with dynamic responses within a few hours, the heat transfer in the borehole region being approximated as a steady-state process has been proven suitable and described by a constant borehole thermal resistance [8]. Li and Zheng [9] developed a 3-dimensional finite-volume model for vertical ground heat exchangers. The surrounding soil was divided into several layers to evaluate the effect of fluid temperature with depth on the thermal process.

Chiasson et al. [10] developed a model in the TRNSYS modeling environment and coupled it to other GSHP system component models for a short time step (hourly or less) system analysis. It was implemented to model a shallow pond's performance as a supplemental heat rejecter in ground source heat pump systems. The model has been validated by comparing simulation results to experimental data collected from two test ponds. Daniel and Rees [11] presented models of a water-to-water heat pump and ground loop heat exchanger implemented in a building's annual energy simulation program (EnergyPlus). The operation of this model was verified by comparing results to analytical values. They concluded that it is possible to represent ground-source heat pump systems flexibly and examine their performance over the extended periods required for proper analysis with these models. Zanchini et al. [12, 13] utilized the software package Comsol Multiphysics 3.4 to study the effects of flow direction and thermal short-circuiting on the performance of small and $100 \mathrm{~m}$ long coaxial ground heat exchangers. A 2-dimensional axisymmetric unsteady heat conduction and convection problem has been considered. The results pointed out that the annulus-in flow direction (fluid inlet in the outer annular passage) is more efficient than the center-in flow direction (fluid inlet in the inner circular tube). In addition, on account of the small length, the effect of thermal short-circuiting is not important, especially if the annulusin flow direction is employed. However, the results revealed that the impact of thermal short-circuiting on the performance of long coaxial borehole heat exchangers is relevant for the long heat exchanger.

Bauera et al. [14] presented a 3-dimensional numerical simulation model for U-tube borehole heat exchangers. They postulated that their approach provides accurate results while substantially reducing the number of nodes and the computation time compared with fully discretized computations such as finite element models. Their model was used to evaluate thermal response test data by the parameter estimation technique. Comparing the model results with those of an analytical model based on the line-source theory further establishes the advantage of the developed transient model, as the test duration can be shortened and results are more accurate. Rees and He [15] presented a 3-dimensional numerical model that includes explicit representations of the circulating fluid and other borehole components, allowing the calculation of dynamic behaviors over short and long timescales. At long timescales, borehole heat transfer seems wellcharacterized by the mean fluid and borehole wall temperature if the circulating fluid velocity is reasonably high. Still, at lower flow rates, this is not the case. The study of the short timescale dynamics has shown that nonlinearities in the temperature and heat flux profiles are noticeable over the whole velocity range of practical interest.

Song et al. [16] developed a 3-dimensional steady-state numerical model for a U-tube geothermal heat exchanger. The influences of depth, porosity, permeability, and heterogeneity of the formation on the performance of the heat exchanger were investigated. Simulation values were validated by results obtained from field tests. The results indicated that the geothermal reservoir's overall velocity is relatively low compared with the flow in the wellbore, mainly due to the high flow resistance. Therefore, they concluded that it is better to install the single U-tube in the homogeneous area of the reservoir to obtain a better heat extraction effect.

Several investigators developed one-dimensional heat transfer models to create a general formula for borehole thermal resistance prediction [17-19]. For example, Gu and O'Neal [17] utilized a steady-state heat transfer simulation based on the cylindrical source model to produce a correlation for the grout resistance for a vertical U-tube ground heat exchanger in the form:

$R_{g}=\frac{\ln \left(\frac{D_{b}}{d_{o}} \sqrt{\frac{d_{o}}{S_{p}}}\right)}{2 \pi k_{g}}$

Shonder and Beck (2000) [18] have formulated the borehole thermal resistance in the form of:

$R_{g}=\frac{\ln \left(\frac{D_{b}}{\sqrt{n} d_{o}}\right)}{2 \pi k_{g}}$

In this expression, the value of $(n)$ is equal to (2) for a single U-tube heat exchanger. More recently, Tarrad (2019) [19] developed a correlation for the prediction of the borehole total thermal resistance $\left(R_{t}\right)$; it was based on the grout thermal resistance estimation from:

$R_{b}=R_{g}+R_{p}$

$R_{p}=\frac{1}{\pi d_{i} h}+\frac{\ln \left(\frac{d_{o}}{d_{i}}\right)}{2 \pi k_{p}}$ 
$R_{g}=\frac{\ln \left(\frac{d_{b}}{d_{e}}\right)}{2 \pi k_{g}}$

$R_{t}=\frac{\ln \left(\frac{d_{b}}{d_{e}}\right)}{2 \pi k_{g}}+R_{p}+R_{S}$

In these mathematical expressions, the equivalent diameter $\left(d_{e}\right)$ was derived to be:

$d_{e}=\frac{d_{b}}{\left(x+\sqrt{x^{2}-1}\right)}$

$x=\frac{d_{b}^{2}+d_{o}^{2}-s_{p}^{2}}{2 d_{b} d_{o}}$

In Equation 4, a value of (0.053) m.K/W was assigned for ground thermal resistance $\left(R_{s}\right)$ per unit depth as suggested by Garbai and Méhes (2008) [20] for steady-state conditions.

In the present study, Comsol Multiphysics 5.4 [21] was utilized to build a 3-dimensional numerical model to investigate the overall heat transfer rate in a ground single and double U-tube heat exchangers operating at steady-state conditions. The double U-tube was arranged in a cross-orientation, as shown in Figure 1. A comparison of results between these heat exchangers was based on the amount of heat transfer to the ground at the steady-state condition. The heat transfer rate was deduced from assessing the water exit temperature from the borehole zone. In addition, this model was investigated for cooling mode; the ground was implemented as a heat sink for the water cooling medium utilized in the condenser of a heat pump. Special attention was paid to the water flow temperature profile with borehole depth for the upward and downward leg sides.

\section{Model Geometry Presentation}

The heat exchanger, borehole, and ground zone system are illustrated in Figure 1 for both of the investigated geometry orientations, single and double U- heat exchangers.



Figure 1.a. Single U-tube heat exchanger 


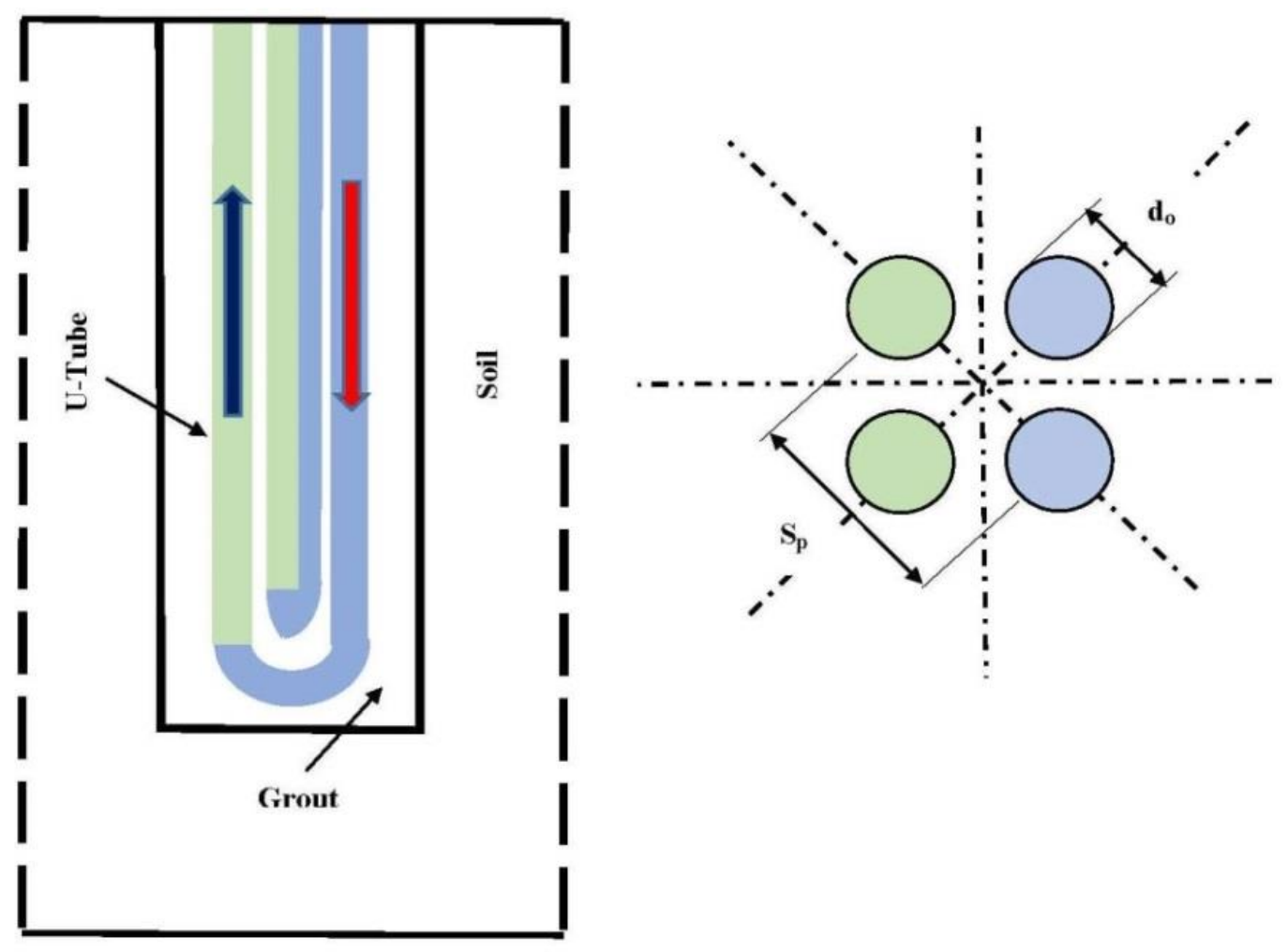

Figure 1.b. Double U-tube heat exchanger

Figure 1. Investigated heat exchanger geometry orientations.

The operating conditions for heat exchangers and their combination with the borehole and soil zones are listed in Table 1.

Table 1. Properties and operating conditions of the geothermal system

\begin{tabular}{lcc}
\hline \multicolumn{1}{c}{ Zone material } & Physical Parameter & Value \\
\hline \multirow{4}{*}{ Water } & $\left(T_{\text {in }}\right),\left({ }^{\circ} \mathrm{C}\right)$ & 33 \\
& $\left(T_{\text {out }}\right),\left({ }^{\circ} \mathrm{C}\right)$ & -- \\
& $\left(P_{\text {in }}\right),(\mathrm{bar})$ & 1 \\
& $\left(v_{\text {in }}\right),(\mathrm{m} / \mathrm{s})$ & $0.2-0.5$ \\
$m_{w},(\mathrm{~kg} / \mathrm{s})$ & $0.14-0.34$ \\
\hline \multirow{3}{*}{$(\mathrm{HDPE})^{*}$ High density } & $\left(k_{H D P E}\right),(\mathrm{W} / \mathrm{m} \mathrm{K})$ & 0.4 \\
polyethylene pipe & $\left(\rho_{H D P E}\right),\left(\mathrm{kg} / \mathrm{m}^{3}\right)$ & 940 \\
& $\left(c p_{H D P E}\right),(\mathrm{J} / \mathrm{kg} \mathrm{K})$ & 2300 \\
\hline \multirow{3}{*}{ Grout $^{*}$} & $\left(k_{g}\right),(\mathrm{W} / \mathrm{m} \mathrm{K})$ & 0.78 \\
& $\left(\rho_{g}\right),\left(\mathrm{kg} / \mathrm{m}^{3}\right)$ & 1000 \\
& $\left(c p_{\mathrm{g}}\right),(\mathrm{J} / \mathrm{kg} \mathrm{K})$ & 1600 \\
\hline \multirow{3}{*}{ Ground $^{*}$} & $\left(k_{s}\right),(\mathrm{W} / \mathrm{m} \mathrm{K})$ & 2.42 \\
& $\left(\rho_{s}\right),\left(\mathrm{kg} / \mathrm{m}^{3}\right)$ & 2800 \\
& $\left(c p_{\mathrm{s}}\right),(\mathrm{J} / \mathrm{kg} \mathrm{K})$ & 840 \\
& $\mathrm{Ground}\left(T_{s}\right),\left({ }^{\circ} \mathrm{C}\right)$ & 16 \\
\hline
\end{tabular}

* Data were taken from reference [22].

Many investigators [23-26] have outlined the operating conditions and recommended a range of potential driving force, the temperature difference, between a ground heat exchanger's downward and upward streams. A temperature difference of (3) degrees is the least permissible temperature difference between the two flow streams in the heat exchanger to ensure proper operation, while higher temperature differences are desirable. For example, Kavanaugh and Rafferty [25] suggested that the heat carrier fluid flowing through the ground heat exchanger should typically be between $5-11^{\circ} \mathrm{C}$ below the undisturbed ground temperature in heating mode and $11-17^{\circ} \mathrm{C}$ above it in cooling one. 


\section{Model Building}

\subsection{Borehole Characteristics}

The geometrical parameters for the numerical model and the combination of different zones are shown in table 2 . The grouting layer thickness beneath the U-tube was kept at (100) $\mathrm{mm}$. The computational domain has included the surrounding soil diameter of $5 \mathrm{~m}$ and a $2.5 \mathrm{~m}$ thick soil layer beneath the U-tube heat exchanger. Heat transfer in solids and heat transfer in fluids with Multiphysics coupling were selected from the Comsol Multiphysics software to solve the built model.

Table 2. Physical dimensions of different zones.

\begin{tabular}{lcc}
\hline \multicolumn{1}{c}{ Zone Material } & Physical Parameter & Value \\
\hline & $\left(d_{o}\right),(\mathrm{mm})$ & 33.4 \\
& $\left(d_{i}\right),(\mathrm{mm})$ & 29.5 \\
& $(t p),(\mathrm{mm})$ & 2.0 \\
(HDPE) $^{*}$ High density polyethylene pipe & $(W F),(---)$ & 17 \\
& $\left(S_{p}\right),(\mathrm{mm})$ & 66.8 \\
& $\left(H_{U-t u b e}\right),(\mathrm{m})$ & 50 \\
\hline \multirow{2}{*}{ Borehole (Grout) } & $\left(d_{b}\right),(\mathrm{mm})$ & 120 \\
& $\left(H_{b}\right),(\mathrm{m})$ & 50.1 \\
\hline \multirow{2}{*}{ Ground } & $\left(d_{s}\right),(\mathrm{m})$ & 5.0 \\
& $\left(H_{s}\right)(\mathrm{m})$ & 52.5 \\
\hline
\end{tabular}

* Dimensional data for the tube were taken from reference [22].

\subsection{Governing Equations}

The governing equations of the present work for the solid and fluid domains are described in Appendix I. The stated equations control the predefined model for the conduction and convection heat transfer modes. Reasonable assumptions are applicable for the case of steady-state conditions to solve the model analytical expressions.

\subsection{Boundary Conditions}

The top ground face of the borehole was assumed as an insulated boundary for the numerical assessment. The far distant surface boundary of the soil was fixed at a constant temperature at $5 \mathrm{~m}$ diameter for the whole borehole depth and the bottom portion of the borehole at the $52.5 \mathrm{~m}$ depth. The U-tubes' exit ports were considered outflow boundaries for the water flow domain, and it possesses a specified entering temperature and flow velocity.

\subsection{Materials}

The thermal properties of all domain materials were specified according to the user-defined category, as shown in Table 1. The water domain for which the built-in library in Comsol Multiphysics 5.4 software was utilized.

\subsection{Geometry Meshing}

The meshing process of the geometry model was conducted by implementing the tetrahedral element type, Figure 2.

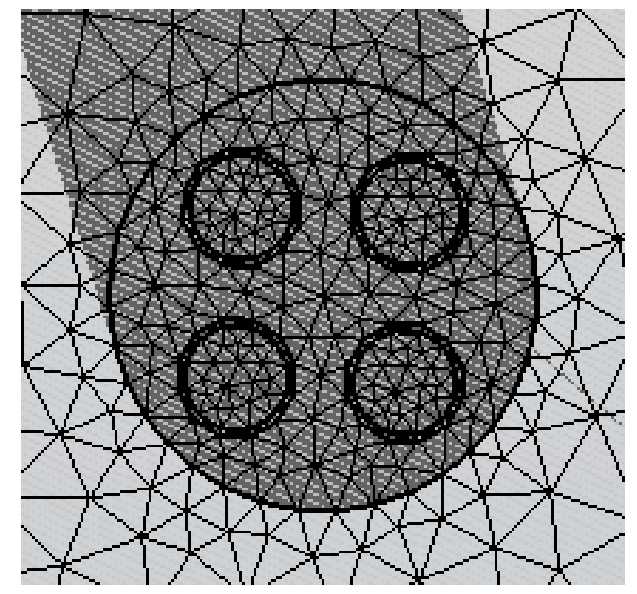

Figure 2.a. Grout and U-tube Meshing

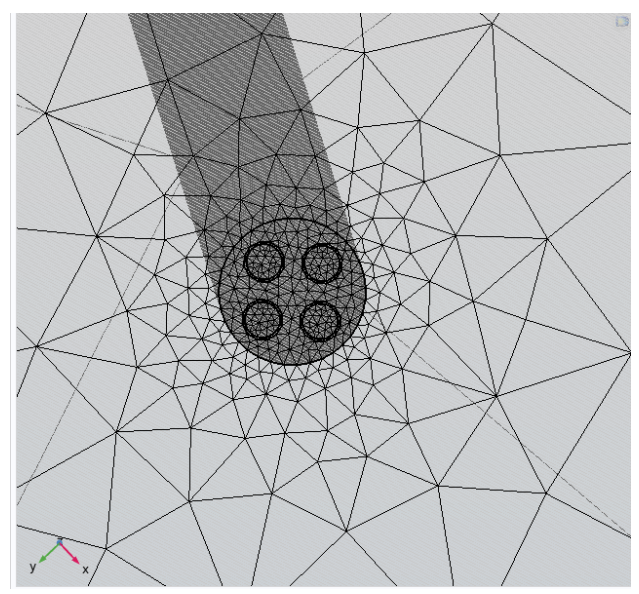

Figure 2.b. Soil Meshing

Figure 2. Borehole geometry meshing 
First, the water domain was meshed according to the fluid dynamic predefined finer element size. Next, the ground or soil domain meshed with the predefined coarser element size. Finally, the other two fields' meshings were performed according to the custom element sizes conducted with specified elements. The element size was selected according to the domain type, fine for the tube, grout, and fluid, and large size for the ground domain to minimize the calculation time, Figure 3.



Figure 3. Element size for meshing

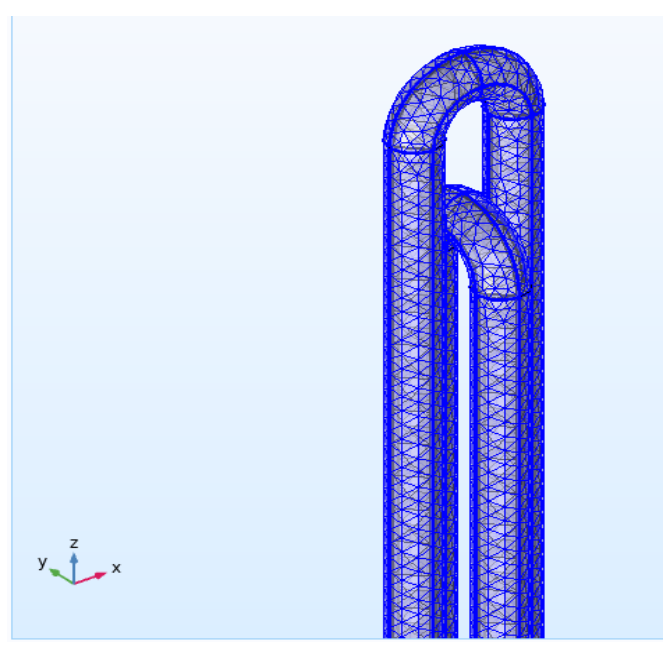

Figure 4. A double U-tube meshing

\section{Assessment Methodology}

Zhu et al. [27] tested a ground heat exchanger in the range of 0.1 and $0.5 \mathrm{~m} / \mathrm{s}$ for water velocity. They recommended the value of $0.3 \mathrm{~m} / \mathrm{s}$ for a borehole depth of $55 \mathrm{~m}$. In the present work, the following operating conditions were examined for a steady-state condition:

- Fixed physical dimensions of all system zones, U-tube, grouting, and soil portion as illustrated in Table 2.

- Fixed water inlet temperature at $306.15 \mathrm{~K}$ as depicted in Table 1 . The flow region fell within the turbulent zone, and the $(k-\varepsilon)$ turbulence model was implemented to solve the energy and flow characteristic equations.

- Variable flow velocity at the inlet leg of the U-tube, it was ranged between 0.2 and $0.5 \mathrm{~m} / \mathrm{s}$. This velocity range produced a mass flow rate that fell within the range of 0.136 and $0.34 \mathrm{~kg} / \mathrm{s}$, respectively.

- For the double U-tube system, the following cases were investigated:

i. The mass flow rate of the single U-tube was utilized for comparison. The tube loading of the single U-tube was divided equally between the two U-tubes. Here, the flow velocity was ranged between 0.1 and $0.25 \mathrm{~m} / \mathrm{s}$.

ii. Keeping the tube loadings constant for each U-tube as the single U-tube one. In effect, double the water mass flow rate of the double U-tube heat exchanger compared to the single U-tube one was used. In addition, the same water flow velocity range was utilized as the single U-tube model.

\section{Results and Discussion}

The output of the Comsol Multiphysics 5.4 software will be divided into two categories, as follows:

\subsection{Water Temperature Distribution}

Figure 5 depicts the temperature variation for both legs of the U-tubes, downward and upward sides, with the depth of the borehole for the double U-tubes model at a single U-tube operation. 




Figure 5. (a) Downward flow

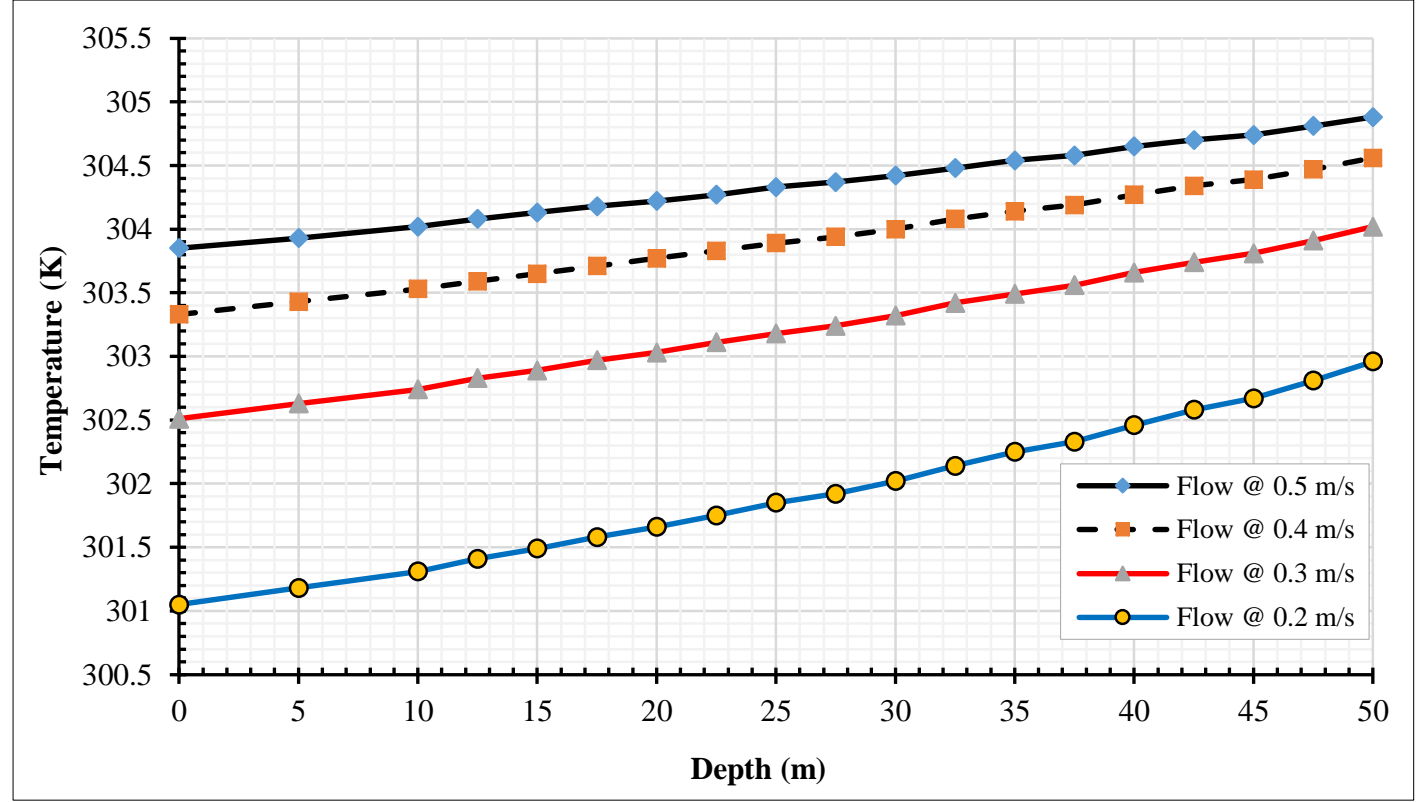

Figure 5. (b) Upward flow

Figure 5. Water temperature distribution comparison at different flow velocities for the single U-tube

The corresponding values of $(\xi)$ for the single U-tube model was ranged between $53 \%$ and $66 \%$ as estimated by Equation 6.

$\xi=\frac{\Delta T_{D W}}{\Delta T_{t}} \times 100$

These numerical values of $(\xi)$ revealed a heat load enhancement for the downward flow leg range to fall within the range $15-43 \%$, respectively, when it was calculated by Equation 7 .

$\eta_{c}=\frac{\Delta T_{\text {leg }-D W}-\Delta T_{\text {leg }-U W}}{\Delta T_{\text {leg }}-D W} \times 100$

The higher values were achieved at, the lower flow velocities and vice versa for both heat exchangers. Figure 6 depicts the temperature variation for both legs of the U-tubes, downward and upward sides, with the depth of the borehole for the double U-tubes model at a half loading operation. The temperature difference for the downward flow at the half loading was ranged between 60 and $76 \%$ of the total temperature difference through the double U-tube heat exchanger as calculated by Equation 6. 


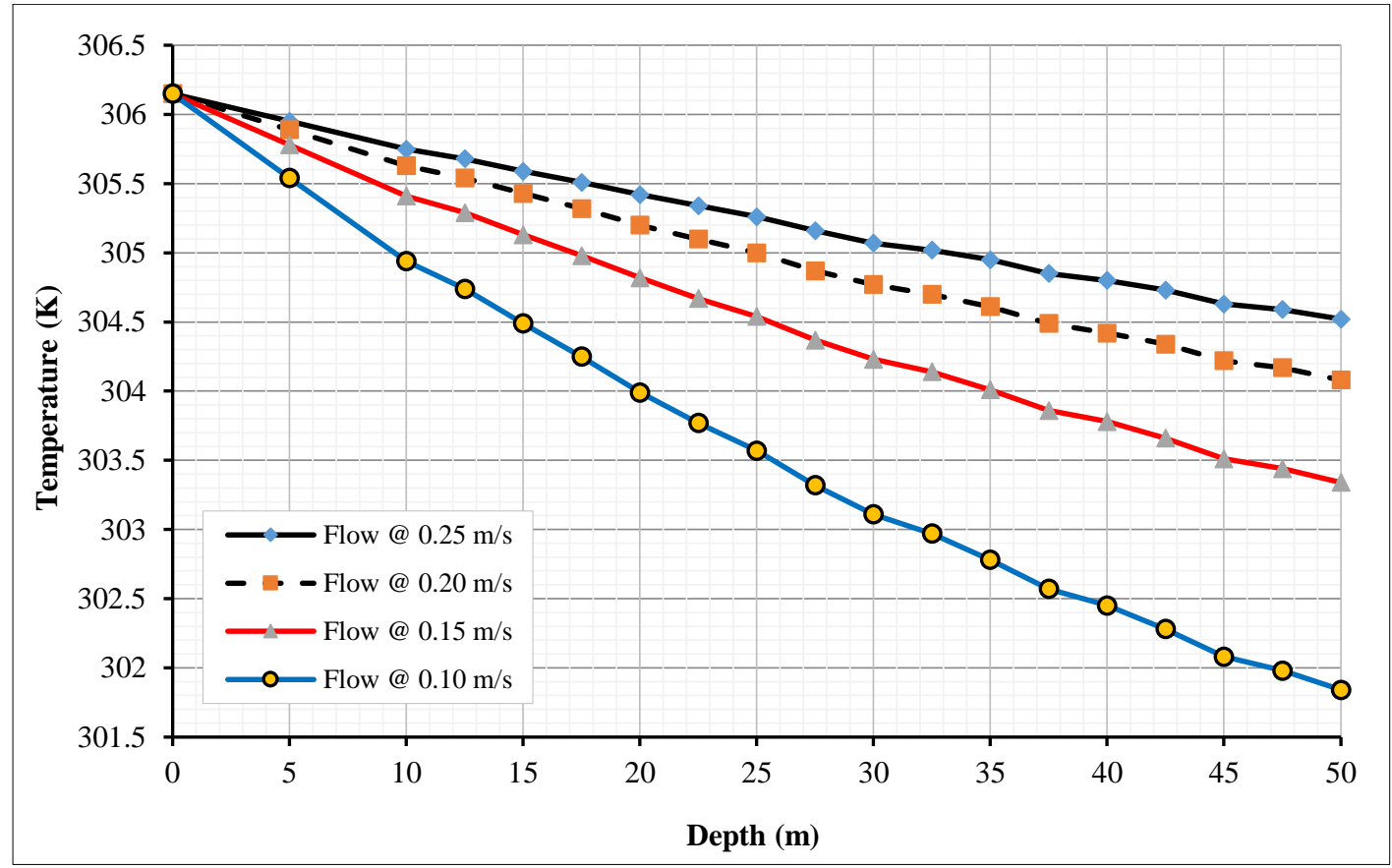

Figure 6. (a) Downward flow



Figure 6. (b) Upward flow

Figure 6. Water temperature distribution comparison at different flow velocities for the half loading double U-tube

Figure 7 depicts the comparison between both geometry orientations at different flow velocities.

The highest temperature difference between the inlet and exit sides of the water was experienced at the lowest examined mass flow rate, which is $0.136 \mathrm{~kg} / \mathrm{s}$, corresponding to $0.2 \mathrm{~m} / \mathrm{s}$. It was 5 and $5.7^{\circ} \mathrm{C}$ for the single and halfloading double U-tube heat exchangers, respectively. The temperature difference values revealed that the cooling load achieved by the downward flow was higher than that of the upward flow side. The $(\xi)$ values produced a heat transfer load enhancement in the downward leg ranging between $35 \%$ and $68 \%$ as calculated from Equation 7. 


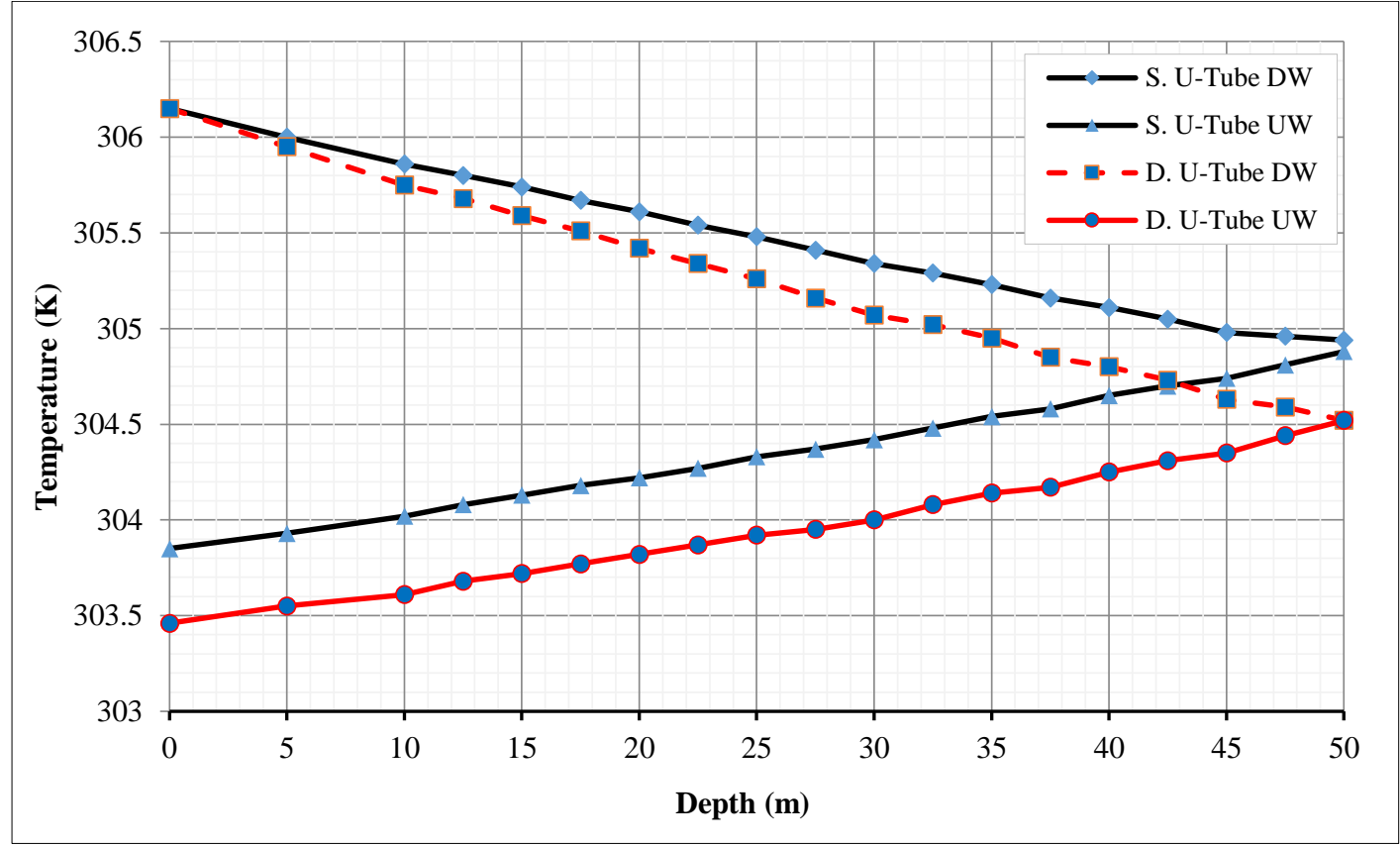

Figure 7.a. Water flow velocity of $(0.5) \mathrm{m} / \mathrm{s}$

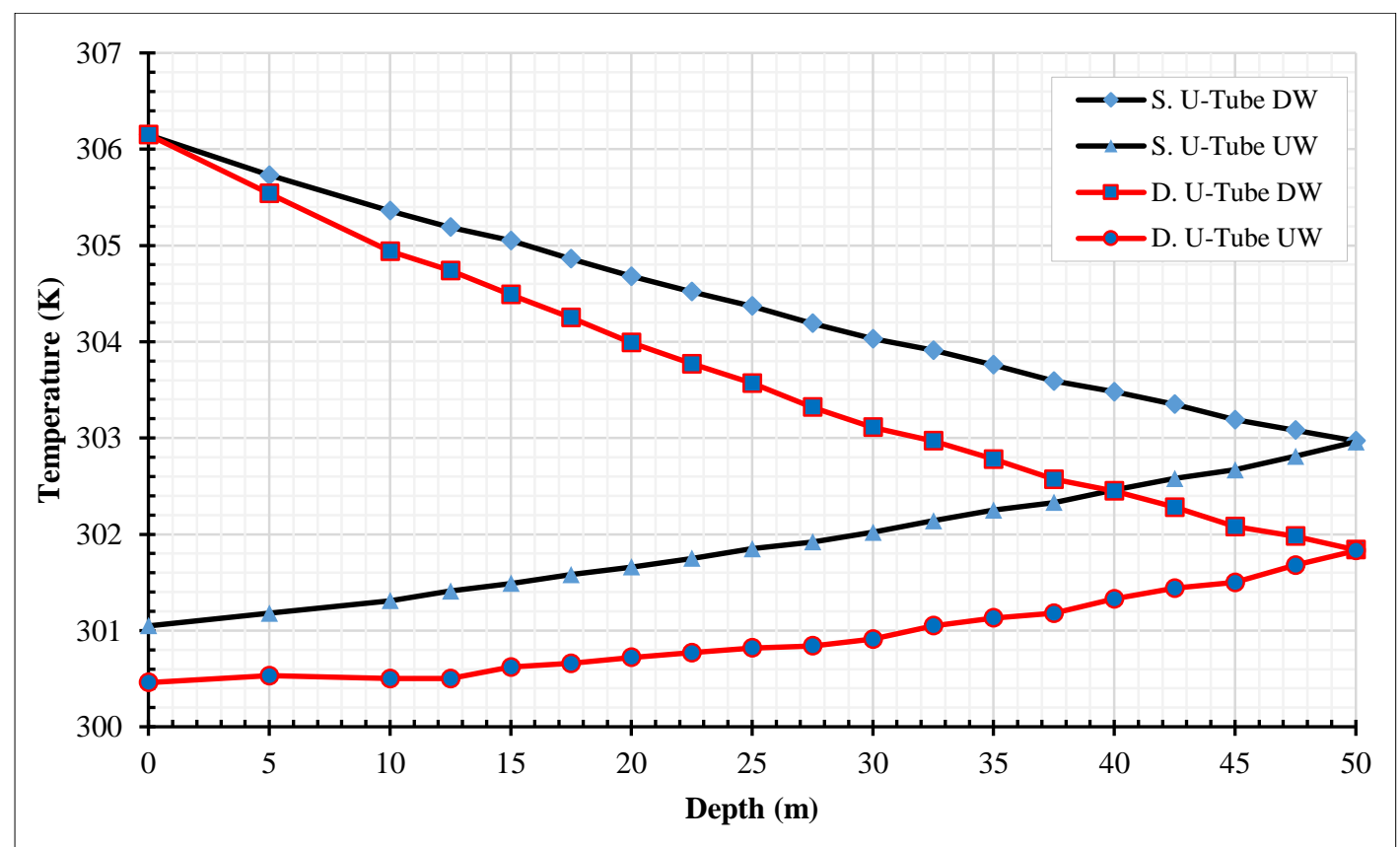

Figure 7.b. Water flow velocity of $(0.2) \mathrm{m} / \mathrm{s}$

Figure 7. Comparison of water temperature variation with depth for various flow orientations at different flow velocities in the downward side of a single U-tube

\subsection{Thermal Analysis}

The heat transfer load of the heat exchanger is predicted from the operating conditions of the water stream as follows:

$\dot{Q}_{H-E}=\dot{m}_{w} c p_{w}\left(T_{w, \text { in }}-T_{w, \text { out }}\right)$

The heat exchanger enhancement heat transfer rate is defined by:

$\varepsilon_{D-S}=\frac{\dot{Q}_{\text {Double }}-\dot{Q}_{\text {Single }}}{\dot{Q}_{\text {Double }}} \times 100$

For a parallel double U-tube system, the mass flow rate of water was equally divided for both U-tubes to produce the half loading scheme of the heat exchanger. The heat exchanger enhancement of the double U-tube compared to the single one is shown in Table 3 . 
Table 3. Heat transfer rate enhancement factor of the double U-tube heat exchanger

\begin{tabular}{|c|c|c|c|c|c|c|}
\hline \multirow{2}{*}{$\begin{array}{c}v_{w} \\
(\mathrm{~m} / \mathrm{s})\end{array}$} & \multirow{2}{*}{$\begin{array}{c}\dot{m}_{w} \\
(\mathrm{~kg} / \mathrm{s})\end{array}$} & \multicolumn{2}{|c|}{ Heat Load $(\mathrm{kW})$} & \multirow{2}{*}{$\begin{array}{c}\varepsilon_{D-S}(\%) \\
\text { Half Loading }\end{array}$} & \multirow{2}{*}{$\begin{array}{c}\text { Heat Load (kW) } \\
\text { Full Loading }\end{array}$} & \multirow{2}{*}{$\begin{array}{c}\varepsilon_{D-S}(\%) \\
\text { Full Loading }\end{array}$} \\
\hline & & Single & Double & & & \\
\hline 0.5 & 0.36 & 3.30 & 3.82 & 13.6 & 4.03 & 18.2 \\
\hline 0.4 & 0.272 & 3.22 & 3.72 & 13.5 & 3.98 & 19.2 \\
\hline 0.3 & 0.204 & 3.10 & 3.55 & 12.5 & 3.89 & 20 \\
\hline 0.2 & 0.136 & 2.90 & 3.23 & 10.4 & 3.72 & 22 \\
\hline
\end{tabular}

Surprisingly, the double U-tube didn't exhibit much heat transfer enhancement despite increasing the heat transfer area by a factor of (2). This enhancement fell within the range of 10.4-13.6\% for the examined operating conditions. This could be attributed to the obstruction of the tube legs to the heat transfer flow between the fluid and the soil. Further, there is a short-circuiting of heat transfer mode between the hot and cold legs of the U-tubes. As a result, the implementation of full loading of fluid flow in the double U-tube has shown only 18-22\% of load enhancement, as shown in Table 3. The comparison of the temperature drop of water as it passes through the ground heat exchanger is shown in Figure 8.

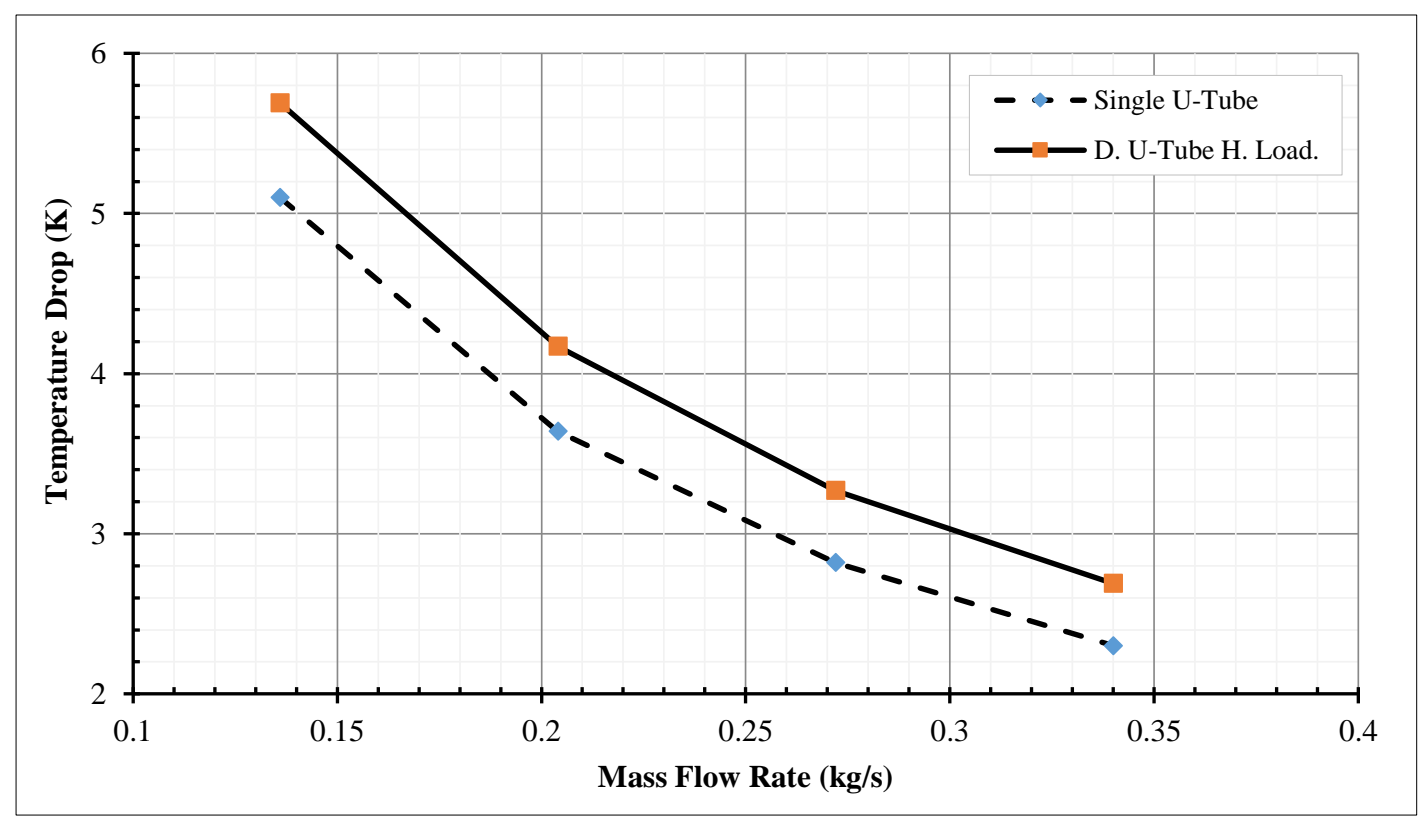

Figure 8. A comparison for the water temperature drop across the single and the half loading double-U-tube heat exchanger

The double U-tube heat exchanger has shown a higher water temperature drop than the single U-tube one by $10.4 \%$ to $14.5 \%$ for the investigated operating conditions. The total resistance of the borehole per unit depth could be estimated from the energy balance between the fluid flow and the ground surface from:

$$
R_{t}=\frac{\Delta T_{m}}{\dot{q}_{H-E}}
$$

Here $\left(\dot{q}_{H-E}\right)$ represents the heat transfer rate per unit length of the heat exchanger depth. The mean temperature difference $\left(\Delta T_{m}\right)$ is defined as:

$\Delta T_{m}=T_{w, m}-T_{s}$

The mean water temperature is calculated by:

$T_{w, m}=\frac{T_{w, i n}+T_{w, o u t}}{2}$

The mean total resistance per unit depth for the single and half loading double U-tube heat exchangers were 0.246 $\mathrm{m} .{ }^{\circ} \mathrm{C} / \mathrm{W}$ and $0.21 \mathrm{~m} .{ }^{\circ} \mathrm{C} / \mathrm{W}$ respectively. Therefore, Equation 12 predicts the deviation of the single U-tube thermal resistance from that of the double U-tube one:

$\beta_{S-D}=\frac{R_{\text {Single }}-R_{\text {Double }}}{R_{\text {Single }}} \times 100$ 
These results showed that the single U-tube resistance was higher than that of the double one by about $14.6 \%$. The present model single U-tube total resistance per unit depth was compared to those predicted when utilizing Equations 1, 2, and 3.c in Table 4.

Table 4. Comparison of the single U-tube total thermal resistance with published correlations

\begin{tabular}{cccc}
\hline Reference & $\begin{array}{c}\boldsymbol{R}_{t} \\
\left(\mathbf{m} .{ }^{\circ} \mathbf{C} / \mathbf{W}\right)\end{array}$ & $\begin{array}{c}\boldsymbol{R}_{t, \text { model }} \\
\left(\mathbf{m} .{ }^{\circ} \mathbf{C} / \mathbf{W}\right)\end{array}$ & $\begin{array}{c}\Delta \boldsymbol{R}_{\boldsymbol{t}} \\
(\boldsymbol{\%})\end{array}$ \\
\hline Gu and O’Neal (1998) [17] & 0.292 & 0.246 & 15.8 \\
Shonder and Beck (1999) [18] & 0.298 & 0.246 & 17.4 \\
$\quad$ Tarrad (2019) [19] & 0.28 & 0.246 & 12.0 \\
\hline
\end{tabular}

The deviation percentage between the correlations' predictions and the model is designated as $\left(\Delta R_{t}\right)$ calculated from:

$\Delta R_{t}=\frac{R_{t, r e f}-R_{t, \text { model }}}{R_{t, \text { ref }}} \times 100$

These correlations overestimated the total thermal resistance of the single U-tube configuration. However, these numerical magnitudes illustrate that Tarrad's [19] correlation predicted a closer value to that of the present 3-dimensional model results. The heat conduction term is more predominant than the heat convection part in the borehole heat transfer process. Therefore, the numerical values of the thermal resistance of both heat exchangers were essentially independent of the water flow velocity.

The half-loading heat exchanger showed a specific heat transfer rate ranging between 65 and $76 \mathrm{~W} / \mathrm{m}$ with a mean value of $71.6 \mathrm{~W} / \mathrm{m}$ based on borehole depth. On the other hand, the respective values for the single U-tube heat exchanger were ranged between $58 \mathrm{~W} / \mathrm{m}$ and $66 \mathrm{~W} / \mathrm{m}$ with a mean value of $62 \mathrm{~W} / \mathrm{m}$. These values of the specific heat transfer rate showed that the double U-tube heat exchanger achieved only $13.4 \%$ enhancement compared to the single U-tube one.

\subsection{Model Temperature Distribution}

The temperature distributions in the solid and water domains were deduced from the postprocessing of the numerical computation and the available flexible technique for data assessment. Figures 9 and 10 illustrate the temperature distribution at the lower portion of the U-tube and grout zones as deduced at various water flow velocities for both heat exchangers.

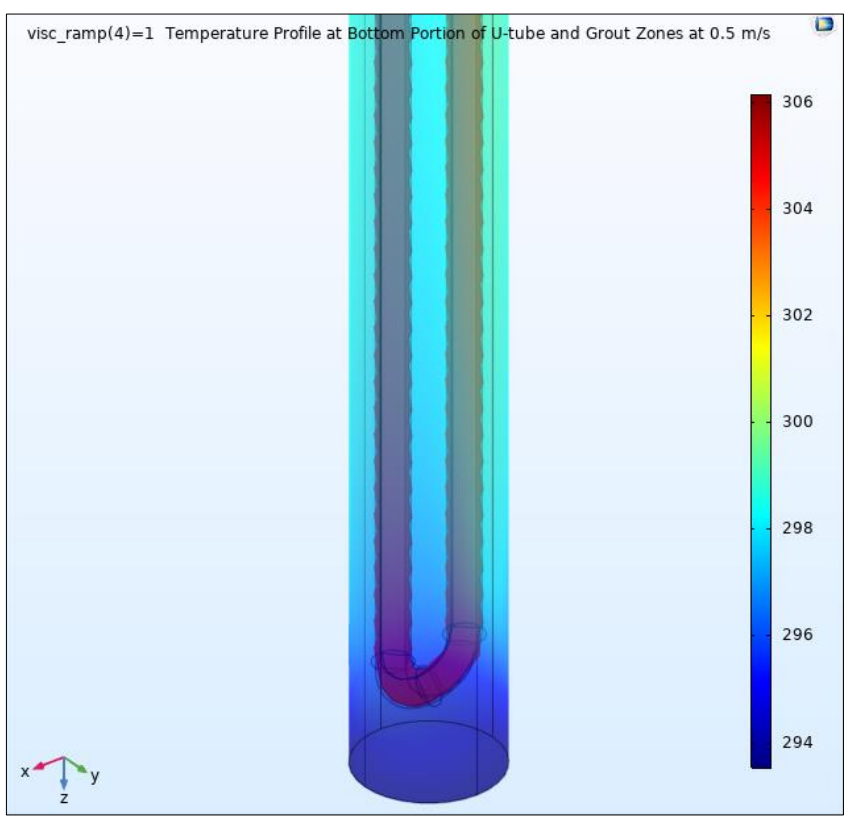

Figure 9.a. Water velocity of $(0.5) \mathrm{m} / \mathrm{s}$



Figure 9.b. Water velocity of $(0.2) \mathrm{m} / \mathrm{s}$

Figure 9. Temperature distribution at the single U-tube and grout for various flow velocities 


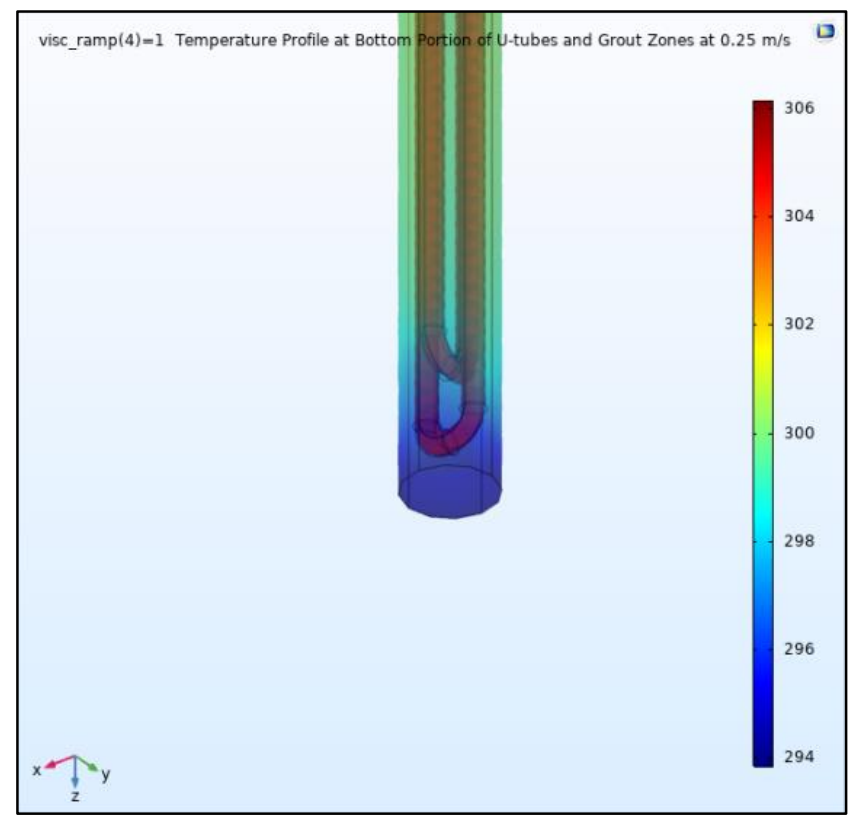

Figure 10.a. Water velocity of $(0.25) \mathrm{m} / \mathrm{s}$

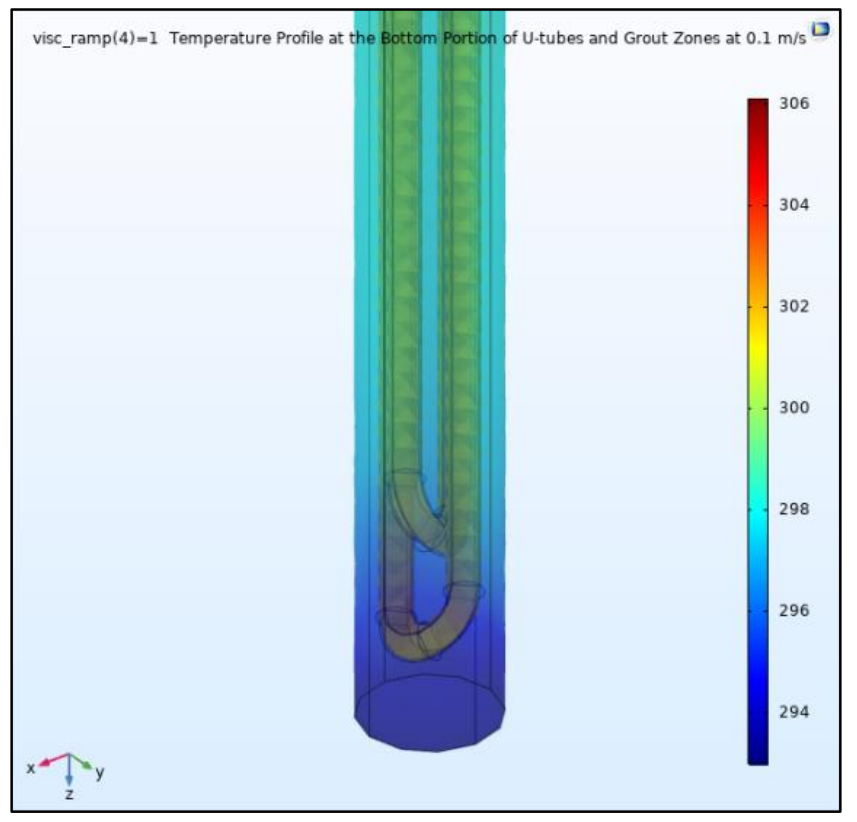

Figure 10.b. Water velocity of $(0.1) \mathrm{m} / \mathrm{s}$

Figure 10. Temperature distribution at the double $U$-tube and grout for various flow velocities.

These figures show a temperature variation for the U-tube/grout system with borehole depth. The lower experienced temperature is shown to be at the bottom portion of the borehole for both geometries. The results for both investigated geometries didn't reveal a circumferential variation. Hence, the temperature at the borehole wall is essentially independent of the circumferential angle. This is due to the low-temperature difference of water in both U-tube legs.

\section{Conclusions}

The present work revealed the following findings:

- A 3-dimensional steady-state model for a single and double U-tube borehole heat exchanger of a ground-heat pump integrated system was built.

- Adding the second U-tube in parallel circuiting didn't enhance much heat transfer enhancement of the single Utube borehole heat exchanger. It was ranged between $10 \%$ and $14 \%$ for flow velocity of $0.2 \mathrm{~m} / \mathrm{s}$ and $0.5 \mathrm{~m} / \mathrm{s}$, respectively.

- The mean resistance per unit length for the single and half loading double U-tube heat exchangers were 0.246 $\mathrm{m} .{ }^{\circ} \mathrm{C} / \mathrm{W}$ and $0.21 \mathrm{~m} .{ }^{\circ} \mathrm{C} / \mathrm{W}$ respectively. This revealed that the single U-tube resistance was higher than that of the double U- tube by about $14.6 \%$.

- Downward water flow experiences a higher temperature drop than the upward stream for both heat exchangers. Its range fell within $53-66 \%$ and $60-76 \%$ of the total temperature drop $\left(\Delta T_{t}\right)$ for the single and double U-tube boreholes, respectively.

- The double U-tube heat exchanger showed a higher water temperature drop $\left(\Delta T_{t}\right)$ than that of the single U-tube one by $10.4-14.5 \%$ for the investigated borehole operating conditions.

- The temperature distribution at the borehole surface didn't show a significant circumferential variation. Hence, it is essentially independent of the circumferential angle.

- The utilization of a full-loading scheme for the double U-tube showed a higher heat transfer rate enhancement than that of the half-loading one. However, the performance enhancement fell in the range of $18 \%$ and $22 \%$ compared to that of the single U-tube one.

\section{Nomenclature}

$\begin{array}{llll}c p & \text { Heat capacity at constant pressure, }(\mathrm{kJ} / \mathrm{kg} \mathrm{K}) & d & \text { Diameter, }(\mathrm{mm}) \\ g & \text { Gravitational acceleration, }\left(\mathrm{m} / \mathrm{s}^{2}\right) & H & \text { Depth, }(\mathrm{m}) \\ k & \text { Thermal conductivity, }(\mathrm{W} / \mathrm{m} . \mathrm{K}) & \dot{m} & \text { Mass flow rate, }(\mathrm{kg} / \mathrm{s}) \\ n & \text { Number of tubes, }(2) \text { for a single U-tube } & p & \text { Pressure, (Pa) or (bar) }\end{array}$




\begin{tabular}{|c|c|c|c|}
\hline$\dot{q}$ & Heat generation per unit volume, $\left(\mathrm{W} / \mathrm{m}^{3}\right)$ & $\dot{q}$ & Specific heat transfer rate, $(\mathrm{W} / \mathrm{m})$ \\
\hline$\dot{Q}$ & Heat transfer rate, $(\mathrm{kW})$ & $r, \theta, z$ & Cylindrical-coordinate variables \\
\hline$R$ & Specific thermal resistance, (m.K/W) & $S_{p}$ & Tube or pipe spacing, (mm) \\
\hline$t$ & Time, $(\mathrm{sec})$ & $t p$ & Pipe thickness, (mm) \\
\hline$T$ & Temperature, $(\mathrm{K})$ & $\Delta T$ & Temperature difference, $(\mathrm{K})$ \\
\hline$u_{r}, u_{\theta}, u_{z}$ & Cylindrical velocity components, (m/s) & $v$ & Water flow velocity, (m/s) \\
\hline$b$ & Borehole & $c$ & Cooling \\
\hline$D F$ & Double U-tube flow & Double & Double U-tube value \\
\hline$D-S$ & Double to single U-tube & $D W$ & Downward flow direction \\
\hline$e$ & Equivalent & $g$ & Grout \\
\hline$H-E$ & Heat exchanger & $i$ & Inside \\
\hline in & Inlet & leg & U-tube leg \\
\hline$m$ & mean & $o$ & Outside \\
\hline out & Outlet & $p$ & Pipe \\
\hline$s$ & Soil or ground & $S-D$ & Single to double U-tube \\
\hline Single & Single U-tube value & $t$ & Total \\
\hline$U W$ & Upward flow direction & $w$ & Water \\
\hline$\alpha$ & Thermal diffusivity, $\left(\mathrm{m}^{2} / \mathrm{s}\right)$ & $\beta$ & The percentage increase of resistance, $(\%)$ \\
\hline$\varepsilon$ & Heat transfer rate enhancement, $(\%)$ & $\xi$ & Temperature ratio percentage, $(\%)$ \\
\hline$\eta$ & Temperature drop increase percentage, $(\%)$ & $\mu$ & Fluid dynamic viscosity, (Pa.s) \\
\hline$\Phi$ & Viscous dissipation rate, $\mathrm{N} /\left(\mathrm{m}^{2} \mathrm{~s}\right)$ & & \\
\hline
\end{tabular}

\section{Declarations}

\subsection{Data Availability Statement}

The data presented in this study are available in article.

\subsection{Funding}

The author received no financial support for the research, authorship, and/or publication of this article.

\subsection{Acknowledgements}

The author expresses his sincere thanks to the administration of the (PAUSE) program in France and the University of Lorraine for their valuable support in completing this work.

\subsection{Declaration of Competing Interest}

The author declares that they have no known competing financial interests or personal relationships that could have appeared to influence the work reported in this paper.

\section{References}

[1] Ingersoll, L. R., Zobel, O. J., \& Ingersoll, A. C. (1955). Heat Conduction with Engineering, Geological, and Other Applications. Physics Today. 8(3). New York, United States. doi:10.1063/1.3061951.

[2] Muttil, N., \& Chau, K. W. (2006). Neural network and genetic programming for modelling coastal algal blooms. International Journal of Environment and Pollution, 28(3-4), 223-238. doi:10.1504/IJEP.2006.011208.

[3] Ingersoll, L. R., Zobel, O. J., \& Ingersoll, A. C. (1955). Heat Conduction with Engineering, Geological, and Other Applications. Physics Today 8(3). University of Wisconsin Press, Madison. doi:10.1063/1.3061951.

[4] Carslaw, H.S. and Jaeger, J.C. (1959). Conduction of heat in solids, (2nd Ed.); Oxford University Press, London, United Kingdom.

[5] Kavanaugh, S. P. (1985). Simulation and experimental verification of vertical ground-coupled heat pump systems. PhD Thesis Oklahoma State University, Stillwater, United States.

[6] Zeng, H., \& Fang, Z. A fluid temperature model for vertical U-tube geothermal heat exchangers. Journal of Shandong Institute of Architecture and Engineering, 17(1), 7-10.

[7] Zeng, H. Y., Diao, N. R., \& Fang, Z. H. (2002). A finite line-source model for boreholes in geothermal heat exchangers. Heat Transfer - Asian Research, 31(7), 558-567. doi:10.1002/htj.10057. 
[8] Yavuzturk, C., Spitler, J. D., \& Rees, S. J. (1999). A Transient two-dimensional finite volume model for the simulation of vertical U-tube ground heat exchangers. ASHRAE Transactions, 105(2), 465-474.

[9] Li, Z., \& Zheng, M. (2009). Development of a numerical model for the simulation of vertical U-tube ground heat exchangers. Applied Thermal Engineering, 29(5-6), 920-924. doi:10.1016/j.applthermaleng.2008.04.024.

[10] Chiasson, A. D., Spitler, J. D., Rees, S. J., \& Smith, M. D. (2000). Model for simulating the performance of a shallow pond as a supplemental heat rejecter with closed-loop ground-source heat pump systems. ASHRAE Transactions, 106(2), $107-121$.

[11] Fisher, D. E., \& Rees, S. J. (2005). Modeling ground source heat pump systems in a building energy simulation program (energyplus). IBPSA 2005 - International Building Performance Simulation Association 2005, 311-318.

[12] Zanchini, E., Lazzari, S., \& Priarone, A. (2010). Effects of flow direction and thermal short-circuiting on the performance of small coaxial ground heat exchangers. Renewable Energy, 35(6), 1255-1265. doi:10.1016/j.renene.2009.11.043.

[13] Zanchini, E., Lazzari, S., \& Priarone, A. (2010). Improving the thermal performance of coaxial borehole heat exchangers. Energy, 35(2), 657-666. doi:10.1016/j.energy.2009.10.038.

[14] Bauer, D., Heidemann, W., \& Diersch, H. J. G. (2011). Transient 3D analysis of borehole heat exchanger modeling. Geothermics, 40(4), 250-260. doi:10.1016/j.geothermics.2011.08.001.

[15] Rees, S. J., \& He, M. (2013). A three-dimensional numerical model of borehole heat exchanger heat transfer and fluid flow. Geothermics, 46, 1-13. doi:10.1016/j.geothermics.2012.10.004.

[16] Song, X., Lyu, Z., Li, G., Sheng, M., Liu, J., Li, R., \& Shi, Y. (2017). Numerical analysis of characteristics of a single U-tube downhole heat exchanger in the geothermal reservoir. Transactions - Geothermal Resources Council, 41, 227-245.

[17] Shonder, J. A., \& Beck, J. V. (1999). Determining effective soil formation thermal properties from field data using a parameter estimation technique. ASHRAE Transactions, 105, 458-466.

[18] Gu, Y., \& O’Neal, D. L. (1998). Development of an equivalent diameter expression for vertical U-tubes used in ground-coupled heat pumps. ASHRAE Transactions, 104(2), 347-355.

[19] H. Tarrad, A. (2019). A Borehole Thermal Resistance Correlation for a Single Vertical DX U-Tube in Geothermal Energy Application. American Journal of Environmental Science and Engineering, 3(4), 75. doi:10.11648/j.ajese.20190304.12.

[20] Garbai, L. (2008). Heat capacity of vertical ground heat exchangers with single U-tube installation in the function of time. WSEAS Transactions on Heat and Mass Transfer, 3(3), 177-186.

[21] COMSOL Multiphysics Version 5.4. (2018). Heat transfer module user guide. COMSOL Inc. Stockholm, Sweden

[22] Sagia, Z., Stegou, A., \& Rakopoulos, C. (2012). Borehole Resistance and Heat Conduction around Vertical Ground Heat Exchangers. The Open Chemical Engineering Journal, 6(1), 32-40. doi:10.2174/1874123101206010032.

[23] Chua, K. J., Chou, S. K., \& Yang, W. M. (2010). Advances in heat pump systems: A review. Applied Energy, 87(12), 36113624. doi:10.1016/j.apenergy.2010.06.014.

[24] Banks, D. (2012). An introduction to thermogeology: Ground source heating and cooling: Second edition. In An Introduction to Thermogeology: Ground Source Heating and Cooling: Second Edition. Blackwell Publishing. doi:10.1002/9781118447512.

[25] Kavanaugh, S. P., \& Rafferty, K. (1997). Design of geothermal systems for commercial and institutional buildings. ASHRAE Transactions (Vol. 17). American Society of Heating, Refrigeration and Air Conditioning Engineers, Georgia, United States.

[26] Bird, R. B. (2002). Transport phenomena. Applied Mechanics Reviews, 55(1), R1-R4. doi:10.1115/1.1424298.

[27] Zhu, L., Chen, S., Yang, Y., \& Sun, Y. (2019). Transient heat transfer performance of a vertical double U-tube borehole heat exchanger under different operation conditions. Renewable Energy, 131, 494-505. doi:10.1016/j.renene.2018.07.073. 


\section{Appendix I}

\section{A.1 Fluid Domain}

The following mathematical expressions describe the conservation equations for the fluid domain, continuity, Navier-Stokes, and energy in an incompressible flow:

\section{A.1.1. Continuity Equation}

$\frac{1}{r} \frac{\partial\left(r u_{r}\right)}{\partial r}+\frac{1}{r} \frac{\partial u_{\theta}}{\partial \theta}+\frac{\partial u_{z}}{\partial z}=0$

\section{A.1.2. Navier-Stokes Equation}

$$
\begin{aligned}
& \rho\left(\frac{\partial u_{r}}{\partial t}+u_{r} \frac{\partial u_{r}}{\partial r}+\frac{u_{\theta}}{r} \frac{\partial u_{r}}{\partial \theta}+u_{z} \frac{\partial u_{r}}{\partial z}-\frac{u_{\theta}^{2}}{r}\right)=\rho g_{r}-\frac{\partial p}{\partial r}+\mu\left[\frac{1}{r} \frac{\partial}{\partial r}\left(r \frac{\partial u_{r}}{\partial r}\right)+\frac{1}{r^{2}} \frac{\partial^{2} u_{r}}{\partial \theta^{2}}+\frac{\partial^{2} u_{r}}{\partial z^{2}}-\frac{2}{r^{2}} \frac{\partial u_{\theta}}{\partial \theta}-\frac{u_{r}}{r^{2}}\right] \\
& \rho\left(\frac{\partial u_{\theta}}{\partial t}+u_{r} \frac{\partial u_{\theta}}{\partial r}+\frac{u_{\theta}}{r} \frac{\partial u_{\theta}}{\partial \theta}+u_{z} \frac{\partial u_{\theta}}{\partial z}+\frac{u_{r} u_{\theta}}{r}\right)=\rho g_{\theta}-\frac{1}{r} \frac{\partial p}{\partial \theta}+\mu\left[\begin{array}{c}
\frac{1}{r} \frac{\partial}{\partial r}\left(r \frac{\partial u_{\theta}}{\partial r}\right)+\frac{1}{r^{2}} \frac{\partial^{2} u_{\theta}}{\partial \theta^{2}}+\frac{\partial^{2} u_{\theta}}{\partial z^{2}}+ \\
\frac{2}{r^{2}} \frac{\partial u_{r}}{\partial \theta}-\frac{u_{\theta}}{r^{2}}
\end{array}\right] \\
& \rho\left(\frac{\partial u_{z}}{\partial t}+u_{r} \frac{\partial u_{z}}{\partial r}+\frac{u_{\theta}}{r} \frac{\partial u_{z}}{\partial \theta}+u_{z} \frac{\partial u_{z}}{\partial z}\right)=\rho g_{z}-\frac{\partial p}{\partial \theta}+\mu\left[\frac{1}{r} \frac{\partial}{\partial r}\left(r \frac{\partial u_{z}}{\partial r}\right)+\frac{1}{r^{2}} \frac{\partial^{2} u_{z}}{\partial \theta^{2}}+\frac{\partial^{2} u_{z}}{\partial z^{2}}\right]
\end{aligned}
$$

\section{A.1.3. Energy Equation}

$\frac{\partial T}{\partial t}+u_{r} \frac{\partial T}{\partial r}+\frac{u_{\theta}}{r} \frac{\partial T}{\partial \theta}+u_{z} \frac{\partial T}{\partial z}=\frac{\dot{q}}{c p}+\alpha\left[\frac{1}{r} \frac{\partial}{\partial r}\left(r \frac{\partial T}{\partial r}\right)+\frac{1}{r^{2}} \frac{\partial^{2} T}{\partial \theta^{2}}+\frac{\partial^{2} T}{\partial z^{2}}\right]+\frac{\Phi}{\rho c p}$

where the viscous dissipation rate is:

$\Phi=2 \mu\left[\left(\frac{\partial u_{r}}{\partial r}\right)^{2}+\left(\frac{1}{r} \frac{\partial u_{\theta}}{\partial \theta}+\frac{u_{r}}{r}\right)^{2}+\left(\frac{\partial u_{z}}{\partial z}\right)^{2}\right]+\mu\left[\left(\frac{1}{r} \frac{\partial u_{r}}{\partial \theta}+\frac{\partial u_{\theta}}{\partial r}-\frac{u_{\theta}}{r}\right)^{2}+\left(\frac{\partial u_{\theta}}{\partial z}+\frac{1}{r} \frac{\partial u_{z}}{\partial \theta}\right)^{2}+\left(\frac{\partial u_{z}}{\partial r}+\frac{\partial u_{r}}{\partial z}\right)^{2}\right]$

These equations represent the complete forms of the handled expressions in the fluid domain for the transient mode. In the present model, the time-dependent parameters were dropped together with the heat generation $(\dot{q})$ and gravity terms $(\rho g)$.

\section{A.2. Solid Domains}

In the solid domains of the model, the following general Fourier's law for the energy equation is applicable:

$\frac{1}{r} \frac{\partial}{\partial r}\left(r \frac{\partial T}{\partial r}\right)+\frac{1}{r^{2}} \frac{\partial}{\partial \theta}\left(r \frac{\partial T}{\partial \theta}\right)+\frac{\partial}{\partial z}\left(\frac{\partial T}{\partial z}\right)+\frac{\dot{q}}{k}=\frac{1}{\alpha} \frac{\partial T}{\partial t}$

Again in this expression, the energy generation per unit volume $\left(q^{\prime}\right)$ and the temperature variation with time set to zero for steady-state conditions. 